\title{
Olanzapine inhibits hepatic apolipoprotein A5 secretion inducing hypertriglyceridemia in schizophrenia patients and mice
}

Xiansheng Huang ${ }^{1}$, Yiqi Zhang ${ }^{2}$, Wenqiang Zhu ${ }^{1}$, Piaopiao Huang ${ }^{1}$, Jingmei Xiao ${ }^{3}$, Yang Yang ${ }^{1}$, Li Shen ${ }^{1}$, Fei Luo ${ }^{1,4}$, Wen Dai ${ }^{1,5}$, Rong $\mathrm{Li}^{6 *}$, Renrong $\mathrm{Wu}^{3 *}$

1. Department of Cardiovascular Medicine, The Second Xiangya Hospital, Central South University, Changsha, Hunan, China.

2. Department of Critical Care Medicine, The First Affiliated Hospital, School of Medicine, Zhejiang University, Hangzhou, China.

3. National Clinical Research Center for Mental Disorders, and Department of Psychaitry, The Second Xiangya Hospital of Central South University, Changsha 410011, Hunan, China.

4. Department of Molecular Genetics, University of Texas Southwestern Medical Center at Dallas, Dallas, Texas, The United States.

5. Department of Medicine, Columbia University Medical Center, New York, The United States.

6. Department of Stomatology, The Second Xiangya Hospital, Central South University, Changsha, Hunan, China.

* Correspondence: Rong Li, Department of Stomatology, The Second Xiangya Hospital, Central South University, Changsha, Hunan, China, 
\#139 Middle Renmin Road, Changsha, Hunan 410011, China (E-mail: rongli@ csu.edu.cn).

Renrong $\mathrm{Wu}$, Department of Mental Health, The Second Xiangya Hospital, Central South University, \#139 Middle Renmin Road, Changsha, Hunan 410011, China (E-mail: wurenrong@csu.edu.cn).

\section{ABSTRACT}

Olanzapine, an antipsychotic drug, was reported to induce hypertriglyceridemia, whereas the underlying mechanism remains incompletely understood. This study was to determine the role of apolipoprotein A5 (apoA5) in olanzapine-induced hypertriglyceridemia. In this study, 36 drug-naive and first-episode schizophrenic adult patients (aged 18-60 years) in a multi-center clinical trial (ClinicalTrials.gov NCT03451734) were enrolled. Before and after olanzapine treatment, plasma lipid and apoA5 levels were detected. Moreover, 21 female C57BL/6 J mice (8 weeks old) were divided into 3 groups ( $\mathrm{n}=7 /$ each group): low-dose olanzapine $(3 \mathrm{mg} / \mathrm{kg} / \mathrm{day})$, high-dose olanzapine ( $6 \mathrm{mg} / \mathrm{kg} / \mathrm{day})$ and control group. After 6 weeks, plasma glucose, lipids and apoA5 as well as hepatic apoA5 protein and mRNA expression in these animals were detected. In our study in vitro, primary mouse hepatocytes and HepG2 cells were treated with olanzapine of 25, 50,100 $\mu \mathrm{mol} / \mathrm{L}$, respectively. After 24 hours, apoA5 protein and mRNA levels in hepatocytes were detected. Our study showed that olanzapine treatment significantly increased plasma triglyceride levels and decreased plasma apoA5 levels in these schizophrenic patients. A significant negative correlation was indicated between plasma triglyceride and apoA5 levels in these patients. Consistently, olanzapine dose-dependently increased plasma triglyceride levels and decreased plasma apoA5 levels in mice. Surprisingly, an elevation of hepatic apoA5 protein levels was detected in mice after olanzapine treatment, with no changes of APOA5 mRNA expression. Likewise, olanzapine increased apoA5 protein 
medRxiv preprint doi: https://doi.org/10.1101/2021.02.26.21252514; this version posted March 1, 2021. The copyright holder for this preprint (which was not certified by peer review) is the author/funder, who has granted medRxiv a license to display the preprint in perpetuity.

It is made available under a CC-BY-NC-ND 4.0 International license .

levels in hepatocytes in vitro, without changes of hepatocyte APOA5 mRNA. Therefore, our study provides the first evidence about the role of apoA5 in olanzapine-induced hypertriglyceridemia. Furthermore, plasma apoA5 reduction, resulting in hypertriglyceridemia, could be attributed to olanzapine-induced inhibition of hepatic apoA5 secretion.

Keywords: Olanzapine, Hypertriglyceridemia, Apolipoprotein A5, Triglyceride.

\section{Introduction}

Schizophrenia is a severe mental disorder with an approximate lifetime prevalence of $1.0 \%$ [1]. Atypical antipsychotics are commonly prescribed as a first-line treatment for schizophrenia because of their effectiveness and much lower rates of extrapyramidal side effects comparing with typical antipsychotics [2]. However, atypical antipsychotics have more metabolic side effects such as weight gain and disturbed glucose and lipid metabolism. Olanzapine is one of the most prescribing atypical antipsychotics for schizophrenia patients [3] and produces overt dyslipidemia that remarkedly increases the morbidity and mortality of coronary heart disease (CHD) $[4,5]$. Previous studies have shown that olanzapine-induced dyslipidemia is characterized with elevation of plasma triglycerides, low-density lipoprotein cholesterol (LDL-C) and total cholesterol, as well as reduction of high-density lipoprotein cholesterol (HDL-C) [6,7]. Of note, hypertriglyceridemia dramatically increases the CHD risk for schizophrenia patients [8-10]. The pathogenetic mechanism of olanzapine-induced hypertriglyceridemia is still not elucidated, although it might be associated with central histamine $\mathrm{H}_{1}$ antagonism and 
increased appetite or with direct impairment of metabolic regulation and alteration of insulin sensitivity.

Apolipoprotein A5 (apoA5), which is a liver-specifically synthesized and secreted protein and considered as a novel member in apolipoprotein family, has been proven to be an important regulator in triglyceride metabolism. Increasing evidences indicate that apoA5 is a potent regulator of triglyceride despite its low concentration in plasma [11-15]. ApoA5 exerts an atheroprotective effect via decreasing plasma levels of triglycerides and triglyceride-rich lipoproteins [16-18]. Fibrates, a widely-used triglyceride-lowering drug, ameliorates hypertriglyceridemia by up-regulating hepatic apoA5 expression $[19,20]$. Specifically, APOA5 genetic polymorphisms are associated with olanzapine-induced dyslipidemia [21, 22]. These data suggest a potential role of apoA5 in olanzapine-related dyslipidemia that was to be investigated in the present study.

\section{Methods}

\section{Human studies}

\section{Participants}

This study was conducted in The Second Xiangya Hospital Central South University, China from January 2018 to June 2019. Participants were assessed for schizophrenia in accordance with criteria established in the Diagnostic and Statistical Manual of Mental Disorders-Fifth Edition (DSM-5; American Psychiatric Pub; 2013) [23]. Moreover, schizophrenia patients aged 18-60 years in their first psychotic 
episode of schizophrenia were included in this study.

Exclusion criteria were as following: 1) concurrent diagnosis of other psychiatric disorders defined in DSM-5; 2) planning to be pregnant, pregnancy or breastfeeding; history of alcohol, cigarettes or other substance use; known medical conditions that might affect metabolism; 3) history of diabetes, hypertension, other cardiovascular diseases, endocrine diseases, lipid disorders or serious chronic diseases (such as liver and kidney dysfunction, heart failure, etc.). This study was performed in accordance with the Declaration of Helsinki [24], and approved by the Ethics Committee of The Second Xiangya Hospital, Central South University. After a complete description of the study to the participants, informed consent was obtained prior to study participation.

\section{Intervention}

The participants were assigned to an 8-week treatment with olanzapine (15-20mg/day at 8:00 p.m.). The dose of olanzapine initiated with $5 \mathrm{mg} /$ day and then titrated to $15-20 \mathrm{mg} /$ day in the first week.

\section{Assessments}

All patients who received the treatment were scheduled to have a clinical evaluation through the scheduled follow-up at weeks 4 and 8 , and 12 . The baseline assessments included demographics, a comprehensive medical history, physical examination, anthropometric measurements (weight and height), and PANSS score. The laboratory tests at baseline included fasting lipids and glucose, liver and renal function, blood counts, and electrocardiogram. At each follow-up visit, all baseline 
medRxiv preprint doi: https://doi.org/10.1101/2021.02.26.21252514; this version posted March 1, 2021. The copyright holder for this preprint (which was not certified by peer review) is the author/funder, who has granted medRxiv a license to display the preprint in perpetuity.

It is made available under a CC-BY-NC-ND 4.0 International license .

clinical evaluations, including physical examination, anthropometric measurements, and laboratory tests, were repeated. The Treatment Emergent Symptom Scale (TESS) [25] was used to record adverse events throughout the clinical trial. PANSS were also evaluated at the end of the trial.

Primary outcomes were the change in fasting plasma triglyceride and apoA5. Levels of plasma apoA5 were determined using ELISA kits from Novus Biologicals (NBP2-68250, USA). The blood glucose and lipids (including triglycerides, cholesterol, LDL-C and HDL-C) were detected by automatic biochemical analyzer.

Secondary outcomes were: 1) the increase in the levels of other lipids, which included HDL-C, LDL-C, total cholesterol; 2) the change of fasting glucose and body mass index (BMI); and 3) psychopathologic symptoms measured by positive and negative symptom scales (PANSS). BMI is calculated as weight in kilograms divided by height in meter squared.

\section{Statistical Analyses}

All continuous variables with normal distribution were expressed as the mean \pm standard error. Changes of parameters (i.e., body mass index, plasma lipid and apoA5 levels) were defined as the amount of their alterations from baseline to endpoint (i.e., 4 and 8 weeks). The continuous variables were analyzed with ANOVA. Pearson analysis was used for correlation test. The $\mathrm{P}$ value was used to indicate statistical difference, and $\mathrm{P}<0.05$ was considered statistically significant.

Pearson analysis was used for correlation test. The $\mathrm{P}$ value was used to indicate statistical difference, and $\mathrm{P}<0.05$ was considered statistically significant. Graphpad Prism 8.0.1 statistical software and SPSS ( Statistical Product and Service Solutions ) were used for statistical analyses of all the data. 


\section{Animal studies}

\section{Animals}

Twenty-one female C57BL/6 J mice (8 weeks old) were purchased from Hunan Stryker Jingda Animal Co., Ltd. All animals were housed under standard conditions with individually ventilated cages with an artificial 12:12-hour light/dark cycle (lights on: 8:00 am) at room temperature $\left(20-25^{\circ} \mathrm{C}\right)$ and fed ad libitum with free access to water. Mice were fed with a regular chow diet containing $4.5 \%$ fat $(0.02 \%$ cholesterol $)$ throughout the experimental period. All experiments were performed in accordance with the National Institute of Health Guide for the Care and Use of Laboratory and approved by the Experimental Animal Ethics Committee of The Second Xiangya Hospital, Central South University.

\section{Treatments}

Administration of drugs was initiated after one week of acclimatization. The mice were randomly categorized into olanzapine and control group. Mice in the low-dose olanzapine group $(\mathrm{n}=7)$ received $3 \mathrm{mg} / \mathrm{kg}$ olanzapine (LY170053, MCE, USA) per day through gavage for 6 weeks, and mice in the high-dose group were treated with $6 \mathrm{mg} / \mathrm{kg}$ for 6 weeks. Control group was administered with $0.01 \mathrm{ml} / \mathrm{g}$ dimethyl sulfoxide (DMSO) once per day by gavage. Olanzapine was dissolved in 0.1\% DMSO. The set of olanzapine dosage in this study was based on previous studies [26-31].

\section{Determination of body weight, sample collection and biochemical} analyses

Body weight of all animals were assessed weekly during the study. At 6 weeks , animals were fasted for 4 hours and then anesthetized by pentobarbital, the liver samples were collected and frozen in liquid nitrogen immediately and then stored in a $-80{ }^{\circ} \mathrm{C}$ freezer for subsequent analyses. The blood samples were collected from heart 
medRxiv preprint doi: https://doi.org/10.1101/2021.02.26.21252514; this version posted March 1, 2021. The copyright holder for this preprint (which was not certified by peer review) is the author/funder, who has granted medRxiv a license to display the preprint in perpetuity.

It is made available under a CC-BY-NC-ND 4.0 International license .

in EDTA-coated tubes and then centrifuged at $4{ }^{\circ} \mathrm{C}$ at $1000 \mathrm{~g}$ for $15 \mathrm{~min}$ to isolate the plasma. The plasma levels of glucose, triglycerides and total cholesterol were measured using Spotchem EZ SP 4430 (ARKRAY, Inc., Kyoto, Japan). The plasma apoA5 levels were determined using ELISA kits from Chemical Book (A104763, China).

\section{Glucose Tolerance Tests}

At the end of the study, all animals underwent a glucose tolerance test (GTT). Mice were fasted for 6 hours with water provided ad libitum from 9 am on the experimental day. Initial blood glucose levels of mice were collected 2 hours prior to GTT. During GTT, blood glucose levels were obtained at 15, 30, 60, 90, and 120 minutes after an i.p. dose of glucose $(1.5 \mathrm{~g} / \mathrm{kg}$ body weight). Blood samples were drawn from the tail vein and analyzed using a Contour Glucometer (Bayer Pharma AG).

\section{Cell studies}

\section{1 . Isolation and culture of primary mouse hepatocytes}

Primary mouse hepatocytes were isolated and purified from C57BL/6 mice with a modified two-step perfusion method described in detail previously [32, 33]. After mice anaesthetized, the hepatic portal vein was cannulated and perfused with Kreb's Ringer containing collagenase IV for $10 \mathrm{~min}$. After the first wash, a second Kreb's Ringer wash containing $\mathrm{CaCl}_{2}$ and Liberase ${ }^{\mathrm{TM}}$ was used for 10 minutes. All solutions were warmed to $37^{\circ} \mathrm{C}$. Hepatocytes were filtered through a gauze mesh and resuspended in DMEM (Dulbecco's modified Eagle's medium), containing 10\% fetal bovine serum, $1 \mathrm{U} / \mathrm{mL}$ of penicillin and $1 \mathrm{mg} / \mathrm{mL}$ of streptomycin. Cells were plated at six orifice in an atmosphere containing $5 \% \mathrm{CO}_{2}$ at $37{ }^{\circ} \mathrm{C}$. 


\section{Culture of HepG2 cells and intervention for cells}

The human hepatoma cell line (HepG2) was cultured in DMEM at an atmosphere containing $5 \% \mathrm{CO} 2$ at $37{ }^{\circ} \mathrm{C}$. HepG2 cells were passaged every 3 days. Both of the primary mouse hepatocytes and HepG2 cells were divided into olanzapine group and control group. In the olanzapine group, 25, 50, $100 \mu \mathrm{mol} / \mathrm{L}$ olanzapine were respectively added into the medium for intervention for 24 hours. Olanzapine was dissolved in pure DMSO (D2650, sigma, USA). Therefore, in the vehicle, only $0.1 \%$ DMSO was added.

\section{Western blot and QPCR analysis.}

\section{Western blot analysis}

For the cell line samples, the cells were washed with ice-cold PBS for three times. RIPA lysis buffer (P0013D, Beyotime Biotechnology, China) containing 1\% $0.5 \mathrm{mM}$ phenylmethanesulfonyl fluoride (PMSF) were added, and the cells were incubated at $4{ }^{\circ} \mathrm{C}$ for $30 \mathrm{~min}$. The cells were collected and centrifuged at $13,000 \mathrm{~g}$ for 15 min at $4^{\circ} \mathrm{C}$ after been mixed with a pipette. The liver tissues were homogenated in RIPA lysis buffer (P0013B, Beyotime Biotechnology, China) containing 1\% 0.5 $\mathrm{mMol} / \mathrm{L}$ phenylmethanesulfonyl fluoride was added at $100 \mathrm{mg} / \mathrm{mL}$, and then incubated for $30 \mathrm{~min}$. Homogenate was centrifugated at $13000 \mathrm{rpm}$ for $15 \mathrm{~min}$ at $4^{\circ} \mathrm{C}$, the supernatant was saved as a protein extract, and the protein levels were quantified using the BCA protein assay kit (CW0014S, CWBIO, China). Protein extracts were mixed with loading buffer and phosphate buffer saline (PBS), and then the mixture was incubated at $95^{\circ} \mathrm{C}$ for $5 \mathrm{~min}$ for degeneration. Protein extracts were separated by SDS-PAGE and transferred to a PVDF membrane. After blocking with 5\% skimmed milk in TBST with $0.1 \%$ Tween 20 for $2 \mathrm{~h}$ at room temperature, the membranes were incubated with primary antibodies overnight at $4{ }^{\circ} \mathrm{C}$. The primary antibodies against apoA5 (\#3335, Cell Signaling technology, USA; sc-373950, Santa Cruz, USA) and 
medRxiv preprint doi: https://doi.org/10.1101/2021.02.26.21252514; this version posted March 1, 2021. The copyright holder for this preprint (which was not certified by peer review) is the author/funder, who has granted medRxiv a license to display the preprint in perpetuity.

It is made available under a CC-BY-NC-ND 4.0 International license .

tubulin (66031-1-lg, Proteintech, USA) were diluted 1:1000 in 5\% milk/-TBST. The secondary goat anti-mouse and anti-rabbit antibodies (SA00001-2, Proteintech, USA; SA00001-1, Proteintech, USA) were diluted 1:5,000 in milk-TBST, and the membranes were incubated with the corresponding secondary antibodies. The bound complexes were detected with Pierce ${ }^{\mathrm{TM}}$ ECL Western Blotting Substrate (32209, Thermo Scientific, USA) and quantified by a Molecular Imager ChemiDoc ${ }^{\mathrm{TM}}$ XRS+ (Bio-Rad).

\section{QPCR analysis}

To further explore the effect of olanzapine on hepatic apoA5 metabolism, APOA5 mRNA expression levels were measured by quantitative real-time PCR (QPCR). Total RNA was extracted from mouse liver tissues, primary mouse hepatocytes and HepG2 cells according to the protocol of the RNA extraction kit (K0731, Thermo Scientific, USA). First-strand cDNA was synthesized with the Revert Aid First Strand cDNA Synthesis Kit (K1622, Thermo Scientific, USA). QPCR was performed with the SYBR Green Select Master Mix (172-5121, Bio-rad, USA). GAPDH were used as the endogenous controls. The primer were synthesized by Tsingke Biological Technology. The sequences of sense and antisense primers were shown in Table 1.

Table1. Oligonucleotide sequences of primers and shRNA targeting human and APOA5 gene

\begin{tabular}{cccc}
\hline Gene & Source & Category & \multicolumn{1}{c}{ Sequences } \\
\hline \multirow{2}{*}{ APOA5 } & Human & Primers & $\begin{array}{l}\text { Forward: 5'-GCC AGC GAC TTC AGG CTT T-3' } \\
\text { Reverse: 5'-AGC TTG CTC AGA ACC TTG CC-3' }\end{array}$ \\
& & & Forward: 5'-TCC TCG CAG TGT TCG CAA G-3' \\
& Mouse & Primers & Reverse: 5'-GAA GCT GCC TTT CAG GTT CTC-3' \\
& & & Forward: 5'-TGT GGG CAT CAA TGG ATT TGG-3' \\
GAPDH & Human & Primers & Reverse: 5'-ACA CCA TGT ATT CCG GGT CAA T-3' \\
& & & Forward: 5'-TGG CCT TCC GTG TTC CTA C-3' \\
GAPDH & Mouse & Primers & Reverse: 5'-GAG TTG CTG TTG AAG TCG CA-3 \\
\hline
\end{tabular}




\section{Statistical analysis for animal and in vitro studies.}

All statistical analyses were carried out with the Graphpad Prism software, and the data was expressed as the mean \pm SEM. Statistical analysis was conducted via one-way analysis of variance followed by Dunnett's t-test, and differences were considered statistically significant at $P<0.05$.

\section{Results}

Olanzapine-induced hypertriglyceridemia is caused by decreasing plasma apoA5 concentrations in schizophrenia patients

We characterized the plasma triglyceride and apoA5 levels in 36 drug-naive and first-episode schizophrenic patients treated with olanzapine monotherapy for 2 months. As shown in Figure 1 and Table 2, after olanzapine treatment, plasma triglyceride levels increased and plasma apoA5 levels decreased significantly at each follow-up session. The plasma levels of triglyceride increased as early as 4 weeks. Over the 8 -week study period, the mean triglyceride levels increased by $0.76 \mathrm{mmol} / \mathrm{l}$ and the mean of apoA5 levels decreased by $48.87 \mathrm{ng} / \mathrm{ml}$. At 8 weeks, $52.78 \%$ patients had hypertriglyceridemia (plasma triglycerides $\geq 1.7 \mathrm{mmol} / \mathrm{l}$ ). To investigate the potential role of apoA5 in olanzapine-induced dyslipidemia, correlation analyses were carried out between plasma apoA5 and lipid levels. It demonstrated that plasma apoA5 levels were significantly negatively correlated with plasma triglyceride levels at 8 weeks $\left(\mathrm{R}^{2}=0.134, P=0.028\right)$ (Figure $\left.1, \mathrm{C}\right)$ after olanzapine treatment, with no correlation indicated between weight gain and plasma triglycerides (Figure 1, D). On stepwise multiple regression analysis of the independent correlation for triglycerides, plasma apoA5 levels were independently associated with triglycerides at $4(\mathrm{P}=0.001)$ and 8 weeks $(\mathrm{P}=0.028)$ after olanzapine treatment (Table 3$)$. 
A

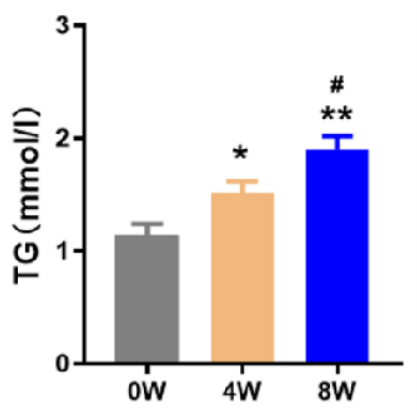

C

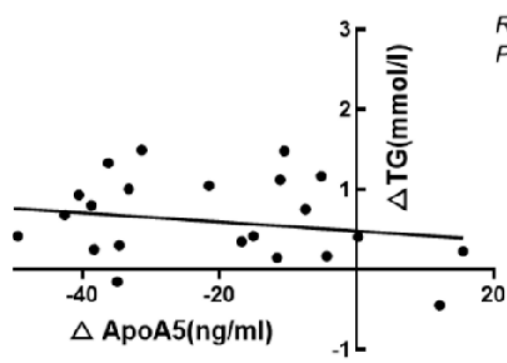

B
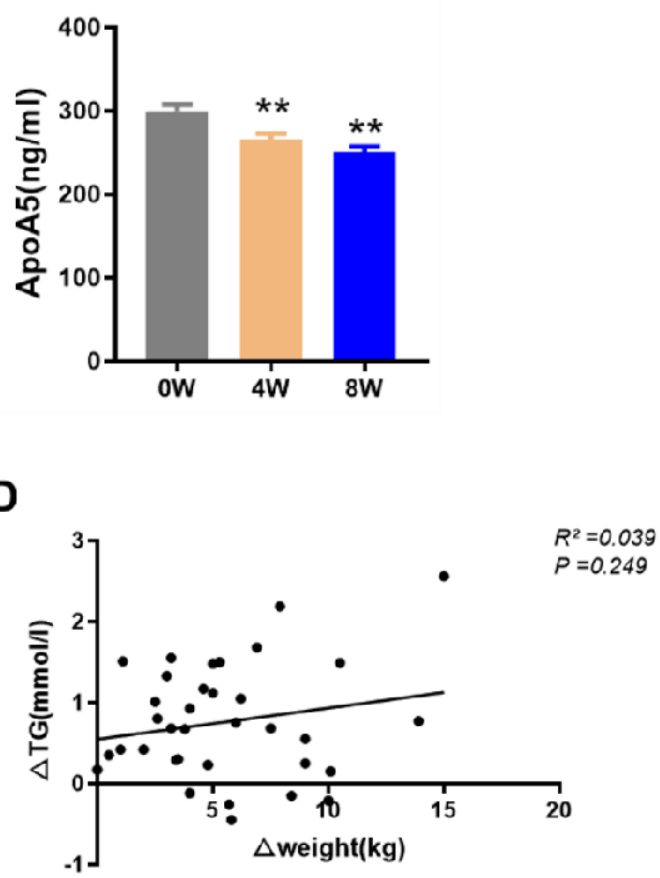

Figure 1. Olanzapine-induced hypertriglyceridemia is caused by decreasing plasma apoA5

levels in schizophrenia patients. (A) Triglyceride (TG) levels. (B) ApolipoproteinA5 (apoA5) levels. The changes in apoA5 $(C)$ and weight $(D)$ correlated with alterations in triglycerides. Results are shown as mean \pm SEM. $* P<0.05$ versus control, $* * P<0.01$ versus control, ${ }^{\#} P<$ 0.05 versus 4-weeks olanzapine treatment.

Table2. Clinical and biochemical characteristics in schizophrenia patients receiving olanzapine therapy

\begin{tabular}{llll}
\hline & Baseline & 4 weeks & 8 weeks \\
\hline Weight $(\mathrm{kg})$ & $59.72 \pm 10.59$ & $62.33 \pm 11.09$ & $65.18 \pm 11.23$ \\
BMI $\left(\mathrm{kg} / \mathrm{m}^{2}\right)$ & $21.39 \pm 3.33$ & $22.30 \pm 3.36$ & $23.32 \pm 3.33^{*}$ \\
Systolic blood pressure & $117.61 \pm 9.08$ & $117.25 \pm 9.09$ & $116.14 \pm 8.69$ \\
$(\mathrm{mmHg})$ & & & \\
Diastolic blood pressure & & & \\
$(\mathrm{mmHg})$ & $71.11 \pm 6.79$ & $71.50 \pm 4.79$ & $70.78 \pm 7.14$ \\
\hline
\end{tabular}


medRxiv preprint doi: https://doi.org/10.1101/2021.02.26.21252514; this version posted March 1, 2021. The copyright holder for this preprint (which was not certified by peer review) is the author/funder, who has granted medRxiv a license to display the preprint in perpetuity.

It is made available under a CC-BY-NC-ND 4.0 International license .

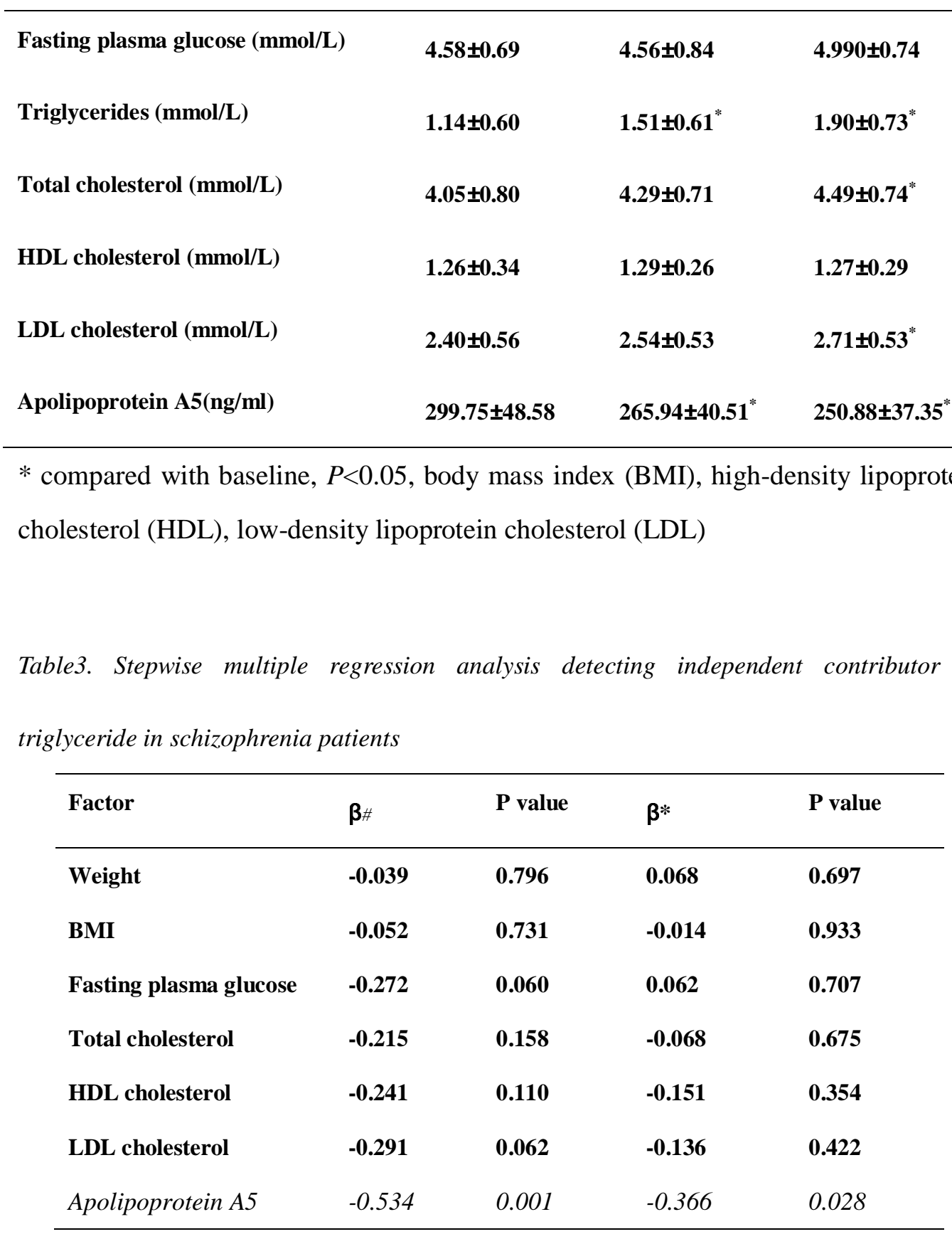

ß: Standardized regression Coefficients. ${ }^{\#}$ : 4-weeks vs baseline, *: 4-weeks vs baseline.

\section{Changes in body weight and glucose and other lipid outcomes}

After 8-week olanzapine treatment, the mean BMI increased significantly by $1.93 \mathrm{~kg} / \mathrm{m}^{2}$ but all patients' BMI were within the normal range $\left(18.5-24 \mathrm{~kg} / \mathrm{m}^{2}\right)$. The plasma levels of total cholesterol, and LDL-C considerably increased, without significant changes in plasma HDL-C and fasting plasma glucose (Supplemental 
medRxiv preprint doi: https://doi.org/10.1101/2021.02.26.21252514; this version posted March 1, 2021. The copyright holder for this preprint (which was not certified by peer review) is the author/funder, who has granted medRxiv a license to display the preprint in perpetuity.

It is made available under a CC-BY-NC-ND 4.0 International license .

Figure 1, B-E). There is no correlation between the difference between body weight and other metabolic indicators.

Effects of olanzapine on body weight, glucose tolerance, blood lipids and apoA5 in mice.

Accumulated data have shown that olanzapine treatment leads to weight gain, impaired glucose tolerance and dyslipidemia in mice [34,35]. In this study, we demonstrated that olanzapine treatment contributed to weight gain and impaired glucose tolerance in a dose-dependent manner in mice (Supplemental materials, Figure 2, A -D). Consistent with the observations in humans, increased plasma triglyceride levels were indicated in the two olanzapine groups $(199.2 \mathrm{mg} / \mathrm{dl}$ in the low-dose olanzapine group and $234.3 \mathrm{mg} / \mathrm{dl}$ in the high-dose olanzapine group, versus $131.4 \mathrm{mg} / \mathrm{dl}$ in control group, both $P<0.05$, Figure 2, A). Compared with the low-dose olanzapine group, the elevation of plasma triglyceride levels was more marked in the high-dose olanzapine group $(P<0.05)$. Meanwhile, our results demonstrated that olanzapine treatment dose-dependently decreased plasma apoA5 levels $(80.90 \mathrm{ng} / \mathrm{ml}$ in the $3 \mathrm{mg} / \mathrm{kg}$ olanzapine group, $66.14 \mathrm{ng} / \mathrm{ml}$ in the $6 \mathrm{mg} / \mathrm{kg}$ olanzapine group, $99.76 \mathrm{ng} / \mathrm{ml}$ in control group, all $\mathrm{P}<0.05$ ) (Figure 2, B) in animals.

\section{Olanzapine increased apoA5 protein levels in mice without changes of APOA5}

gene expression. ApoA5 is specifically produced in the liver and hence secreted into bloodstream, in which this protein predominantly plays a triglyceride-lowering role $[11,12]$. To investigate the potential role of apoA5 for olanzapine-induced hypertriglyceridemia, we detected apoA5 levels in mice liver. Unpredictably, hepatic apoA5 protein levels dramatically enhanced in mice with 8 weeks of olanzapine treatment (Figure 2, C and D). Interestingly, no statistically significant difference of hepatic APOA5 mRNA expression was detected among the three groups $(P>0.05)$ (Figure 2, E). 
A

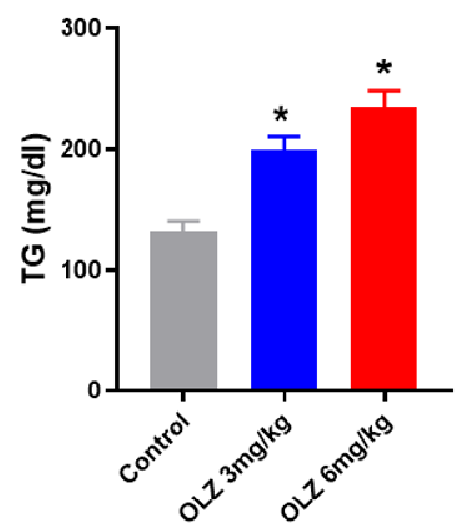

B

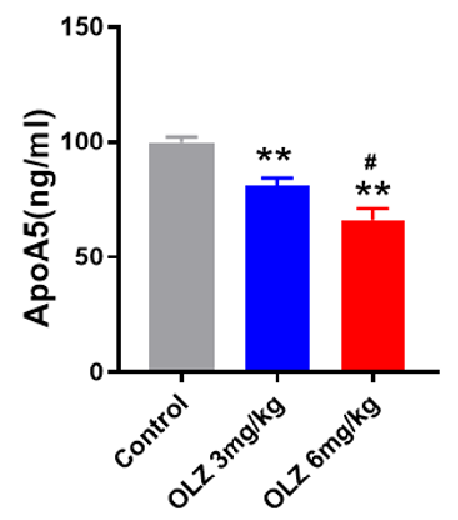

C

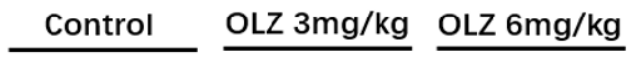

ApoA5

$\alpha$ tubulin

D

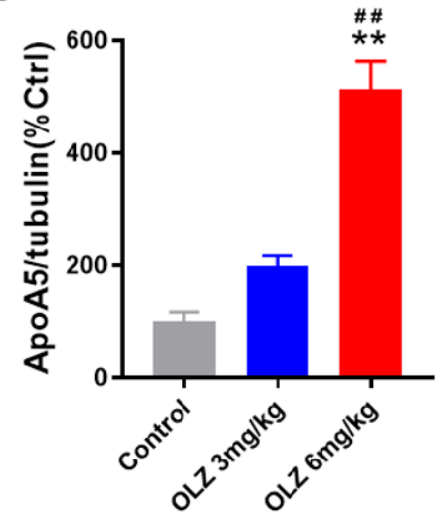

E

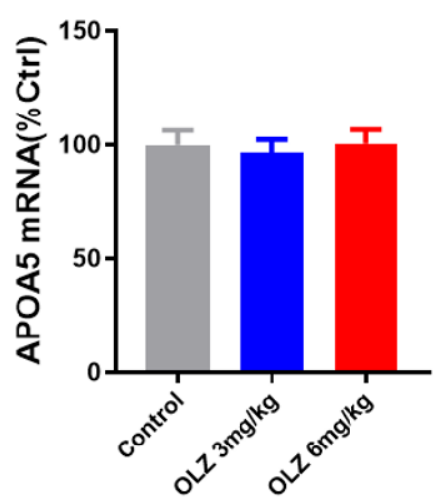

Figure 2. The effect of olanzapine treatment on triglyceride and apoA5 in mice. (A) Plasma triglyceride (TG) levels. (B) Plasma apoA5 levels by ELISA analysis. (C and D) Hepatic apoA5 protein expression in mice by Western blot analysis. (E) Hepatic APOA5 mRNA expression in mice by QPCR analysis. Results are shown as mean \pm SEM. $* P<0.05$ versus control group, ${ }^{* * P}<0.01$ versus control group, \#P $<0.05$ versus OLZ 3mg/kg group.

Olanzapine increased apoA5 protein levels in hepatocytes in vitro, without changes of hepatocyte APOA5 mRNA levels.

To explore the above unpredicted findings of apoA5 in animals, we detected the effects of olanzapine on apoA5 protein and mRNA expression in human and mouse 
medRxiv preprint doi: https://doi.org/10.1101/2021.02.26.21252514; this version posted March 1, 2021. The copyright holder for this preprint (which was not certified by peer review) is the author/funder, who has granted medRxiv a license to display the preprint in perpetuity.

It is made available under a CC-BY-NC-ND 4.0 International license .

hepatocytes in vitro. Similar to the findings in the animal study, our results in vitro showed that olanzapine intervention dose-dependently up-regulated apoA5 protein levels in human and mouse hepatocytes cells (Figure 3, A and C). However, we did not found any effect on APOA5 mRNA levels in hepatocytes in vitro (Figure 3, B and D). These observations in vitro are in accord with our data in vivo from mice, which consistently show that olanzapine administration enhances hepatic apoA5 protein levels instead of hepatic APOA5 mRNA expression.

A

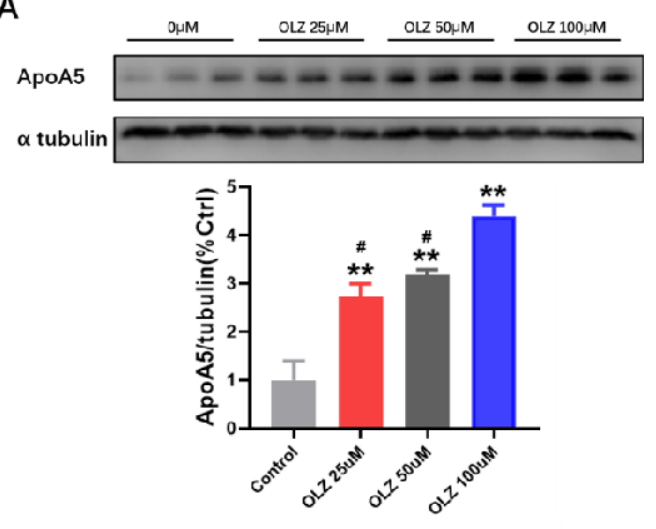

B

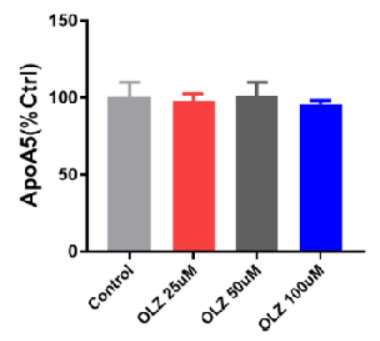

C
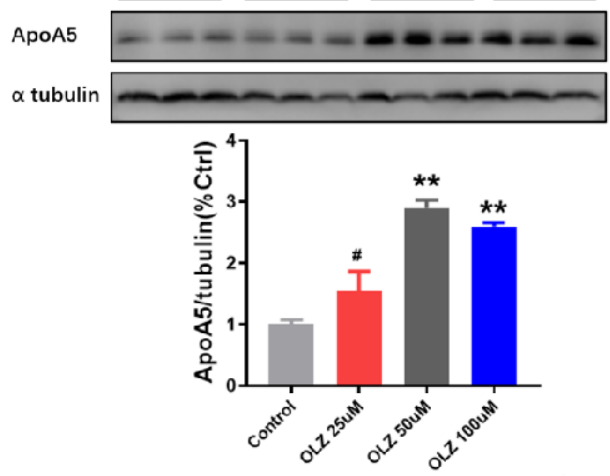

D

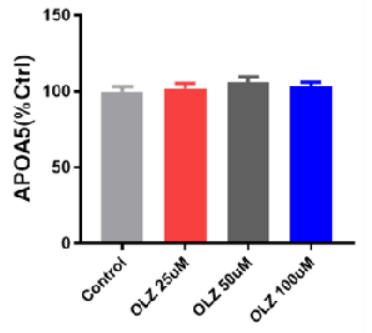

Figure 3. ApoA5 protein and APOA5 mRNA expression in human and mouse hepatocytes in vitro. (A) ApoA5 protein expression in HepG2 cells by Western blot analysis. (B) APOA5 mRNA expression in HepG2 cells by QPCR analysis. (C) ApoA5 protein expression in primary mouse hepatocytes by Western blot analysis. (D) APOA5 mRNA expression in primary mouse hepatocytes by $Q P C R$ analysis. Results are shown as mean $\pm S E M$. $* P<0.05$ versus control group, $* * P<0.01$ versus control group, \#P $<0.05$ versus olanzapine (OLZ) $100 u$ M group.

\section{Discussion}


medRxiv preprint doi: https://doi.org/10.1101/2021.02.26.21252514; this version posted March 1, 2021. The copyright holder for this preprint (which was not certified by peer review) is the author/funder, who has granted medRxiv a license to display the preprint in perpetuity.

It is made available under a CC-BY-NC-ND 4.0 International license .

In this study, our findings implicate that inhibition of hepatic apoA5 secretion contributes to olanzapine-induced hypertriglyceridemia. We observed for the first time that olanzapine medication dramatically reduces plasma apoA5 levels which negatively correlated with increased plasma triglyceride levels in schizophrenia patients. Likewise, we got the same finding that olanzapine induced hypertriglyceridemia through decreasing plasma apoA5 levels in mice. Unpredictably, olanzapine remarkably enhanced hepatic apoA5 protein levels and did not change hepatic APOA5 mRNA expression in mice. Furthermore, similar results of apoA5 protein and mRNA expression were consistently demonstrated in human and mouse hepatocytes in our study in vitro. Taken together, our findings suggest that inhibition of hepatic apoA5 secretion (instead of apoA5 production) by olanzapine, resulting in reduced circulating apoA5 levels, leads to hypertriglyceridemia in schizophrenia patients receiving olanzapine medication.

Studies by us and others have previously shown that long-term olanzapine medication predisposes schizophrenia patients to metabolic syndrome (including weight gain, insulin resistance, diabetes and dyslipidemia, etc.) that confers a significant increase in risk of CHD [5, 36-38]. Among olanzapine-induced metabolic syndrome, dyslipidemia plays a crucial role in the development of $\mathrm{CHD}$, which typically displays as the proatherogenic dyslipidemia triad, i.e., elevated plasma triglycerides, decreased HDL-C, and formation of small dense low-density lipoprotein. Among the proatherogenic dyslipidemia triad, hypertriglyceridemia is the key involving the pathogenesis of the other two dyslipidemia, which is acknowledged as an independent risk factor for CHD [39]. Thus, hypertriglyceridemia is regarded as the central olanzapine-induced dyslipidemia. Similarly, our human and animal data in this study indicated that hypertriglyceridemia was the most representative olanzapine-induced dyslipidemia, as evidenced by our previous meta-analysis study [7]. To date, however, the mechanisms underlying olanzapine-induced hypertriglyceridemia remain to be elucidated.

In the present study, apoA5 was enlisted as a candidate contributor for olanzapine-induced hypertriglyceridemia, which is based on the fact that apoA5 has 
medRxiv preprint doi: https://doi.org/10.1101/2021.02.26.21252514; this version posted March 1, 2021. The copyright holder for this preprint (which was not certified by peer review) is the author/funder, who has granted medRxiv a license to display the preprint in perpetuity.

It is made available under a CC-BY-NC-ND 4.0 International license .

been well-documented as a key regulator for triglyceride metabolism. A large body of animal and human data have implicated apoA5 in reducing plasma triglyceride levels [40-42]. The athero-protective role of apoA5 has also been identified by data from genetically engineered mouse models [16-18], which suggests apoA5 as a potential therapeutic target for treatment of CHD. Specifically, several genetic studies have identified APOA5 gene polymorphisms as a contributing factor for atypical antipsychotics-associated dyslipidemia [43, 44]. We and others previously also confirmed that up-regulation of hepatic apoA5 expression is responsible for the triglyceride-lowering effect of fibrates [19, 20]. More interestingly, we demonstrated that metformin, a drug for treatment of olanzapine-induced dyslipidemia by our previous data [45], ameliorates obesity-associated hypertriglyceridemia in mice via the apoA5 pathway [46]. Thus, these findings raise the intriguing possibility that apoA5 could participate in olanzapine-related hypertriglyceridemia. In this study, we found that olanzapine treatment considerably increased plasma triglyceride levels and decreased plasma apoA5 levels in schizophrenia patients, with a negative correlation observed between triglycerides and apoA5 levels. Interestingly, however, weight gain was not significantly correlated with plasma triglyceride or apoA5 levels in these patients within the duration of the study, which suggests no marked impact of weight gain on plasma triglyceride or apoA5 levels in this study. It is inconsistent with the previous findings that olanzapine-induced obesity, resulting from diet (high fat diet) and lifestyle (less exercise) changes, participates in dyslipidemia in schizophrenia patients [47]. Notedly, the average BMI of all patients $\left(18.5-24 \mathrm{~kg} / \mathrm{m}^{2}\right)$ in our study did not yet reached the criteria of obesity, which is partly due to the short duration of study (i.e. only 8 weeks of olanzapine treatment). Anyway, our findings indicates an alternative metabolic mechanism for olanzapine-induced hypertriglyceridemia, i.e., olanzapine, independent of obesity due to diet and lifestyle changes, directly leads to hypertriglyceridemia via the apoA5 pathway.

The triglyceride-lowering effect of apoA5 is mainly involving three pathways. First and the most important, apoA5 is specifically synthesized in the liver and afterward secreted into the bloodstream [11-14], in which apoA5 activates lipoprotein 
medRxiv preprint doi: https://doi.org/10.1101/2021.02.26.21252514; this version posted March 1, 2021. The copyright holder for this preprint (which was not certified by peer review) is the author/funder, who has granted medRxiv a license to display the preprint in perpetuity.

It is made available under a CC-BY-NC-ND 4.0 International license .

lipase-mediated triglyceride hydrolysis resulting in reduced plasma triglyceride levels [46- 48]. Secondly, hepatic apoA5 inhibits the production and secretion of very low-density lipoprotein in the liver [48]. Finally, hepatic apoA5 promotes uptake of triglyceride-rich lipoproteins remnants by the liver, thereby accelerating triglyceride degradation [50]. Given the fact that apoA5 is a liver-specific protein [11, 12], we speculated that reduced plasma apoA5 levels in human and mice in this study could be a consequence of decreased hepatic apoA5 production, which results in olanzapine-induced hypertriglyceridemia. Unexpectedly, however, we found that olanzapine leads to an elevation (not reduction) of apoA5 protein levels in mouse livers and hepatocytes (human and mouse) in vitro, but no observed effect of olanzapine on APOA5 mRNA in vivo and in vitro. Therefore, our results suggest that reduced plasma apoA5 levels in humans and mice are likely attributed to posttranslational disturbance of hepatic apoA5 protein turnover. Considering the contribution of hepatic apoA5 production and secretion for plasma apoA5 levels, we hold that inhibition of hepatic apoA5 secretion on a posttranslational level, instead of apoA5 production (because of no changes of $A P O A 5 \mathrm{mRNA}$ expression in vivo and in vitro by olanzapine), leads to olanzapine-induced hypertriglyceridemia in these schizophrenia patients and mice.

Our above assumption is consistent with the seemingly paradoxical roles of apoA5 in extra- and intra-hepatic triglyceride metabolism, i.e., apoA5 reduce plasma triglyceride levels and increase hepatocyte triglyceride accumulation [51]. ApoA5 represses hydrolysis of triglycerides and facilitates accumulation of lipid droplets in hepatocytes that promotes the pathogenesis of non-alcoholic fatty liver disease (NAFLD), a disease characterized by excessive triglyceride-rich lipid droplets in hepatocytes $[42,52,53]$. Pursuant to this, olanzapine significantly attenuates hepatic apoA5 secretion, thereby retaining apoA5 in hepatocytes, which is potentially attributable to the development of NAFLD for schizophrenia patients. Indeed, several lines of data have confirmed that olanzapine induces hepatic lipogenesis that likely increases the susceptibility to NAFLD [54-56]. Concomitantly, olanzapine-induced hepatic lipid accumulation is associated with activation of sterol regulatory 
medRxiv preprint doi: https://doi.org/10.1101/2021.02.26.21252514; this version posted March 1, 2021. The copyright holder for this preprint (which was not certified by peer review) is the author/funder, who has granted medRxiv a license to display the preprint in perpetuity.

It is made available under a CC-BY-NC-ND 4.0 International license .

element-binding protein [56], a transcription factor involved in hepatic apoA5 expression [57]. Therefore, although it has yet to be determined, these previous data suggest a potential link between olanzapine-induced hepatic apoA5 retention and excess hepatic lipid accumulation that could promote NAFLD pathogenesis in schizophrenia patients.

Here, we propose a hypothesis for the role of apoA5 in olanzapine-induced hypertriglyceridemia (Figure 4). Physiologically, apoA5 protein is synthesized within the endoplasmic reticulum in hepatocytes, transported into the Golgi body, and hence secreted into the blood for reducing circulating triglyceride levels. However, olanzapine significantly attenuates hepatic apoA5 secretion, resulting in reduced plasma apoA5 levels and hence hypertriglyceridemia. Concomitantly, inhibition of hepatic apoA5 secretion will cause hepatocyte apoA5 retention, thereby facilitating biogenesis of triglyceride-rich lipid droplets and therefore leading to the development of NAFLD.

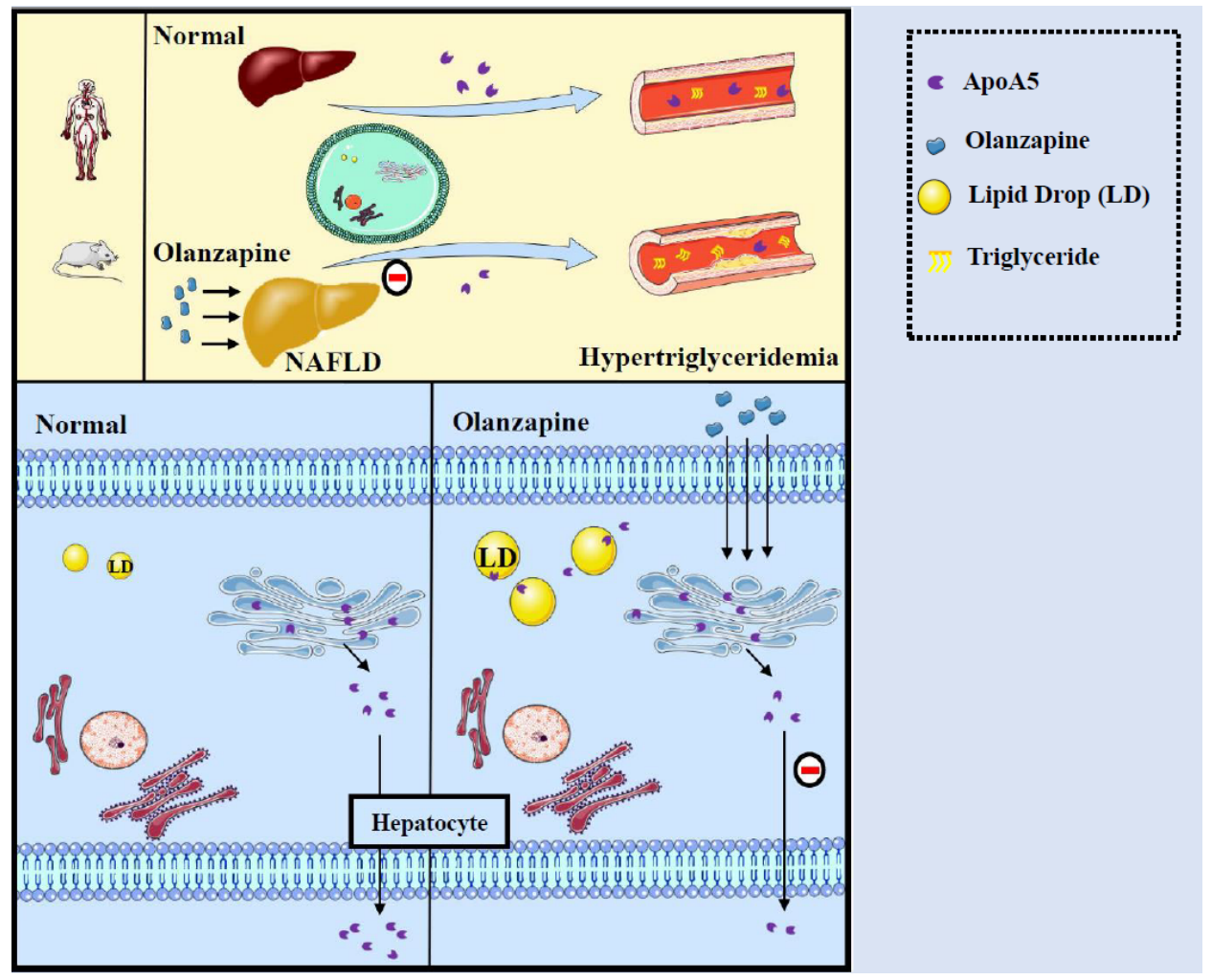

Figure 4: Inhibition of hepatic apoA5 secretion by olanzapine leads to hypertriglyceridemia 
medRxiv preprint doi: https://doi.org/10.1101/2021.02.26.21252514; this version posted March 1, 2021. The copyright holder for this preprint (which was not certified by peer review) is the author/funder, who has granted medRxiv a license to display the preprint in perpetuity.

It is made available under a CC-BY-NC-ND 4.0 International license .

and potentially NAFLD (non-alcoholic fatty liver disease). ApoA5, apolipoprotein A5; LD, lipid droplet.

\section{Conclusion}

This study for the first time investigated the role of apoA5 in olanzapine-induced hypertriglyceridemia. Our findings indicate that olanzapine treatment inhibits hepatic apoA5 secretion, resulting in decreased plasma apoA5 levels and hence increased plasma triglyceride levels. These data suggests that apoA5 may serve as a target for developing therapeutics for hypertriglyceridemia in schizophrenia patients taking olanzapine medication. However, the mechanisms underlying olanzapine-induced inhibition of hepatic apoA5 secretion remains to be investigated in the future.

\section{Authors and contributors}

Xiansheng Huang designed the experiments. Wenqiang Zhu, Piaopiao Huang and Jingmei Xiao performed the experiments. Yang Yang, Li Shen, Fei Luo and Wen Dai analysed the data. Xiansheng Huang, Wenqiang Zhu and Piaopiao Huang prepared the initial draft of the manuscript. Renrong Wu and Rong Li revised the text. All authors approved the final draft of the manuscript.

\section{Declaration of interests}

We declare no competing interests.

\section{Data Availability Statement}

All data used to support the findings of this study are included within the article and supplemental materials. 
medRxiv preprint doi: https://doi.org/10.1101/2021.02.26.21252514; this version posted March 1, 2021. The copyright holder for this preprint (which was not certified by peer review) is the author/funder, who has granted medRxiv a license to display the preprint in perpetuity.

It is made available under a CC-BY-NC-ND 4.0 International license .

\section{Acknowledgments}

This work was supported by the Key R\&D Program Projects, National Science Foundation of China (Grant No.2016YFC1306900), the National Natural Science Foundation of China (Grant No. 81974281 and No. 82072096), the Natural Science Foundation of Hunan Province (No.2017JJ2351; No. 2018JJ3741; No.2020JJ2052), the National Natural Science Foundation for Young Programs of China (No. 81700999).

\section{References}

[1] CHARLSON FJ, FERRARI AJ, SANTOMAURO DF, Global epidemiology and burden of schizophrenia: findings from the global burden of disease study 2016, Schizophr Bull. 44(6) ( 2018) 1195-1203.

[2] LEUCHT S, CIPRIANI A, SPINELI L, Comparative efficacy and tolerability of 15 antipsychotic drugs in schizophrenia: a multiple-treatments meta-analysis, Lancet. 382 (9896) (2013) 951-962.

[3] KINON BJ, AHL J, ROTELLI MD, Efficacy of accelerated dose titration of olanzapine with adjunctive lorazepam to treat acute agitation in schizophrenia, Am J Emerg Med. 22(3) (2004) 181-186.

[4] DE HERT M, DETRAUX J, VAN WINKEL R, Metabolic and cardiovascular adverse effects associated with antipsychotic drugs, Nat Rev Endocrinol. 8(2) (2011) 114-126.

[5] Marder SR, Cannon TD, Schizophrenia, N Engl J Med. 381(18) (2019) $1753-1761$.

[6] Hirsch L, Yang J, Bresee L, Jette N, Patten S, Pringsheim T, Second-Generation Antipsychotics and Metabolic Side Effects: A Systematic Review of Population-Based Studies, Drug Saf. 40(9) (2017) 771-781.

[7] Li R, Zhang Y, Zhu W, Ding C, Dai W, Su X, Dai W, Xiao J, Xing Z, Huang X, Effects of olanzapine treatment on lipid profiles in patients with schizophrenia: a 
medRxiv preprint doi: https://doi.org/10.1101/2021.02.26.21252514; this version posted March 1, 2021. The copyright holder for this preprint (which was not certified by peer review) is the author/funder, who has granted medRxiv a license to display the preprint in perpetuity.

It is made available under a CC-BY-NC-ND 4.0 International license .

systematic review and meta-analysis, Sci Rep. 10(1) (2020) 170.

[8] Henderson DC, Vincenzi B, Andrea NV, Ulloa M, Copeland PM, Pathophysiological mechanisms of increased cardiometabolic risk in people with schizophrenia and other severe mental illnesses, Lancet Psychiatry. 2 (2015) 452-464.

[9] Meyer JM, A retrospective comparison of weight, lipid, and glucose changes between risperidone- and olanzapine-treated inpatients: metabolic outcomes after 1 year, J Clin Psychiatry. 63 (2015) 425-433.

[10] Wirshing DA, Boyd JA, Meng LR, Ballon JS, Marder SR, Wirshing WC, The effects of novel antipsychotics on glucose and lipid levels, J Clin Psychiatry. 63 (2002) $856-865$

[11] Pennacchio LA, Olivier M, Hubacek JA, Cohen JC, Cox DR, Fruchart JC, Krauss RM, An apolipoprotein influencing triglycerides in humans and mice revealed by comparative sequencing, Science. 294 (2001) 169-173.

[12] Nvan der Vliet HN, Sammels MG, Leegwater AC, Levels JH, Reitsma PH, Boers W, Chamuleau RA, Apolipoprotein A-V: a novel apolipoprotein associated with an early phase of liver regeneration, J Biol Chem. 276 (2001) 44512-44520.

[13] PENNACCHIO LA, OLIVIER M, HUBACEK JA, An apolipoprotein influencing triglycerides in humans and mice revealed by comparative sequencing, Science. 294(5540) (2001) 169-173.

[14] RENSEN PC, VAN DIJK KW, HAVEKES LM, Apolipoprotein AV: low concentration, high impact, Arterioscler Thromb Vasc Biol. 25(12) (2005) 2445-2447.

[15] Baroukh N, Bauge E, Akiyama J, Chang J, Afzal V, Fruchart JC, Rubin EM, Analysis of apolipoprotein A5, c3, and plasma triglyceride concentrations in genetically engineered mice, Arterioscler Thromb Vasc Biol. 24 (2004) 1297-1302.

[16] Lookene A, Beckstead JA, Nilsson S, Olivecrona G, Ryan RO, Apolipoprotein A-V-heparin interactions: implications for plasma lipoprotein metabolism. J Biol Chem.,280(27) (2005)25383-7.

[17] Mansouri RM, Baugé E, Gervois P, Fruchart-Najib J, Fiévet C, Staels B, Fruchart JC. Atheroprotective effect of human apolipoprotein A5 in a mouse model of mixed dyslipidemia. Circ Res. 103(5) (2008),450-3. 
medRxiv preprint doi: https://doi.org/10.1101/2021.02.26.21252514; this version posted March 1, 2021. The copyright holder for this preprint (which was not certified by peer review) is the author/funder, who has granted medRxiv a license to display the preprint in perpetuity.

It is made available under a CC-BY-NC-ND 4.0 International license .

[18] Grosskopf I, Shaish A, Afek A, Shemesh S, Harats D, Kamari Y. Apolipoprotein A-V modulates multiple atherogenic mechanisms in a mouse model of disturbed clearance of triglyceride-rich lipoproteins. Atherosclerosis. 224(1) (2012),75-83.

[19] Brautbar A, Covarrubias D, Belmont J, Lara-Garduno F, Virani SS, Jones PH, Leal SM, Variants in the APOA5 gene region and the response to combination therapy with statins and fenofibric acid in a randomized clinical trial of individuals with mixed dyslipidemia, Atherosclerosis. 219 (2011) 737-742.

[20] Huang XS, Zhao SP, Bai L, Hu M, Zhao W, Zhang Q, Atorvastatin and fenofibrate increase apolipoprotein AV and decrease triglycerides by up-regulating peroxisome proliferator-activated receptor-alpha, $\mathrm{Br}$ J Pharmacol. 158 (2009) 706-712.

[21] Smith RC, Segman RH, Golcer-Dubner T, Allelic variation in ApoC3, ApoA5 and LPL genes and first and second generation antipsychotic effects on serum lipids in patients with schizophrenia, Pharmacogenomics J. 8(3) (2008) 228-236.

[22] Hong CJ, Chen TT, Bai YM, Impact of apolipoprotein A5 (APOA5)

polymorphisms on serum triglyceride levels in schizophrenic patients under

long-term atypical antipsychotic treatment, World J Biol Psychiatry. 13(1) (2012) 22-29.

[23] Battle DE. Diagnostic and Statistical Manual of Mental Disorders (DSM).

Codas. 2013;25(2):191-2.

[24] General Assembly of the World Medical Association. World Medical Association Declaration of Helsinki: ethical principles for medical research involving human subjects. J Am Coll Dent. 2014 Summer;81(3):14-8.

[25] Guy W: ECDEU Assessment Manual for Psychopharmacology, Revised. Rockville, MD, US Department of Health, Education, and Welfare: Public Health Service, Alcohol, Drug Abuse and Mental Health Administration.

[26] Coccurello R, Brina D, Caprioli A, Conti R, Ghirardi O, Schepis F, 30 days of continuous olanzapine infusion determines energy imbalance, glucose intolerance, insulin resistance, and dyslipidemia in mice, J Clin Psychopharmacol. 29 (2009) 576-583. 
medRxiv preprint doi: https://doi.org/10.1101/2021.02.26.21252514; this version posted March 1, 2021. The copyright holder for this preprint (which was not certified by peer review) is the author/funder, who has granted medRxiv a license to display the preprint in perpetuity.

It is made available under a CC-BY-NC-ND 4.0 International license .

[27] Shertzer HG, Kendig EL, Nasrallah HA, Johansson E, Genter MB, Protection from olanzapine-induced metabolic toxicity in mice by acetaminophen and tetrahydroindenoindole, Int J Obes. 34 (2010) 970-979.

[28] Yoon S, Noh JS, Choi SY, Baik JH, Effects of atypical antipsychotic drugs on body weight and food intake in dopamine D2 receptor knockout mice, Biochem Biophys Res Commun. 393 (2010) 235-241.

[29] Schmidt RH, Jokinen JD, Massey VL, Falkner KC, Shi X, Yin X, Olanzapine activates hepatic mammalian target of rapamycin: new mechanistic insight into metabolic dysregulation with atypical antipsychotic drugs, J Pharmacol Exp Ther. 347 (2013) 126-135.

[30] Alexander GC, Gallagher SA, Mascola A, Moloney RM, Stafford RS, Increasing off label use of antipsychotic medications in the United States, 1995-2008,

Pharmacoepidemiol Drug Saf. 20 (2011) 177-84.

[31] De Hert M, Detraux J, van Winkel R, Yu W, Correll CU, Metabolic and cardiovascular adverse effects associated with antipsychotic drugs, Nat Rev Endocrinol. 8 (2011) 114-126.

[32]. Klaunig JE, Goldblatt PJ, Hinton DE, Lipsky MM, Chacko J, Trump BF. Mouse liver cell culture. I Hepatocyte isolation. In vitro. 17(10) (1981)913-25.

[33] Klaunig JE, Goldblatt PJ, Hinton DE, Lipsky MM, Trump BF. Mouse liver cell culture. II Primary culture. In vitro. 17(10) (1981)926-34.

[34] Li R, Ou J, Li L, Yang Y, Zhao J, Wu R, The Wnt Signaling Pathway Effector TCF7L2 Mediates Olanzapine-Induced Weight Gain and Insulin Resistance, Front Pharmacol. 9:379 (2018)

[35] Lord CC, Wyler SC, Wan R, Castorena CM, Ahmed N, Mathew D, Lee S, Liu C, Elmquist JK, The atypical antipsychotic olanzapine causes weight gain by targeting serotonin receptor 2C, J Clin Invest. 127(9) (2017) 3402-3406

[36] Musil R, Obermeier M, Russ P, Hamerle M, Weight gain and antipsychotics: a drug safety review, Expert Opin Drug Saf. 14 (2015) 73-96.

[37] Wu RR, Zhao JP, Liu ZN, Zhai JG, Guo XF, Guo WB, Tang JS, Effects of typical 
medRxiv preprint doi: https://doi.org/10.1101/2021.02.26.21252514; this version posted March 1, 2021. The copyright holder for this preprint (which was not certified by peer review) is the author/funder, who has granted medRxiv a license to display the preprint in perpetuity.

It is made available under a CC-BY-NC-ND 4.0 International license .

and atypical antipsychotics on glucose-insulin homeostasis and lipid metabolism in first-episode schizophrenia, Psychopharmacology (Berl). 186 (2006) 572-578.

[38] Wu RR, Zhao JP, Jin H, Shao P, Fang MS, Guo XF, He YQ, Liu YJ, Chen JD, Li $\mathrm{LH}$, Lifestyle intervention and metformin for treatment of antipsychotic-induced weight gain: a randomized controlled trial, JAMA. 299(2) (2008) 185-93.

[39] MILLER M, STONE NJ, BALLANTYNE C, Triglycerides and cardiovascular disease: a scientific statement from the American Heart Association, Circulation. 123(20) (2011) 2292-2333.

[40] PENNACCHIO LA, OLIVIER M, HUBACEK JA, An apolipoprotein influencing triglycerides in humans and mice revealed by comparative sequencing, Science, 294(5540) (2001) 169-173.

[41] ZHAO SP, HU S, LI J, Association of human serum apolipoprotein A5 with lipid profiles affected by gender, Clin Chim Acta. 376(1-2) (2007) 68-71.

[42] FORTE TM, RYAN RO, Apolipoprotein A5: Extracellular and Intracellular Roles in Triglyceride Metabolism, Curr Drug Targets. 16(12) (2015) 1274-1280.

[43] SMITH RC, SEGMAN RH, GOLCER-DUBNER T, Allelic variation in ApoC3, ApoA5 and LPL genes and first and second generation antipsychotic effects on serum lipids in patients with schizophrenia, Pharmacogenomics J. 8(3) (2008) 228-236.

[44] HONG CJ, CHEN TT, BAI YM, Impact of apolipoprotein A5 (APOA5) polymorphisms on serum triglyceride levels in schizophrenic patients under long-term atypical antipsychotic treatment, World J Biol Psychiatry. 13(1) (2012) 22-29.

[45] Wu RR, Zhang FY, Gao KM, Ou JJ, Shao P, Jin H, Guo WB, Chan PK, Zhao JP, Metformin treatment of antipsychotic-induced dyslipidemia: an analysis of two randomized, placebo-controlled trials, Mol Psychiatry. 21(11) (2016) 1537-1544.

[46] Li R, Chen LZ, Zhao W, Zhao SP, Huang XS, Metformin ameliorates obesityassociated hypertriglyceridemia in mice partly through the apolipoprotein A5 pathway, Biochem Biophys Res Commun. 478(3) (2016)1173-8.

[47] ALBERTI KG, ECKEL RH, GRUNDY SM, Harmonizing the metabolic syndrome: a joint interim statement of the International Diabetes Federation Task Force on Epidemiology and Prevention; National Heart, Lung, and Blood Institute; 
medRxiv preprint doi: https://doi.org/10.1101/2021.02.26.21252514; this version posted March 1, 2021. The copyright holder for this preprint (which was not certified by peer review) is the author/funder, who has granted medRxiv a license to display the preprint in perpetuity.

It is made available under a CC-BY-NC-ND 4.0 International license .

American Heart Association; World Heart Federation; International Atherosclerosis Society; and International Association for the Study of Obesity, Circulation. 120(16) (2009) 1640-1645.

[48] Zheng XY, Zhao SP, Yan H, The role of apolipoprotein A5 in obesity and the metabolic syndrome, Biol Rev Camb Philos Soc. 88(2) (2013) 490-8

[49] GROSSKOPF I, BAROUKH N, LEE SJ, Apolipoprotein A-V deficiency results in marked hypertriglyceridemia attributable to decreased lipolysis of triglyceride-rich lipoproteins and removal of their remnants, Arterioscler Thromb Vasc Biol. 25(12) (2005) 2573-2579.

[50] SCHAAP FG, RENSEN PC, VOSHOL PJ, ApoAV reduces plasma triglycerides by inhibiting very low density lipoprotein-triglyceride (VLDL-TG) production and stimulating lipoprotein lipase-mediated VLDL-TG hydrolysis, J Biol Chem. 279(27) (2004) 27941-27947.

[51] Feng Q, Baker SS, Liu W, Arbizu RA, Aljomah G, Khatib M, Nugent CA, Baker RD, Forte TM, Hu Y, Zhu L, Increased apolipoprotein A5 expression in human and rat non-alcoholic fatty livers, Pathology. 47(4) (2015) 341-8.

[52] Shu X, Nelbach L, Ryan RO, Forte TM, Apolipoprotein A-V associates with intrahepatic lipid droplets and influences triglyceride accumulation, Biochim Biophys Acta. 1801(5) ( 2010) 605-8.

[53] Gao X, Forte TM, Ryan RO, Influence of apolipoprotein A-V on hepatocyte lipid droplet formation, Biochem Biophys Res Commun. 427(2) (2012) 361-5.

[54] Oh KJ, Park J, Lee SY, Hwang I, Kim JB, Park TS, Lee HJ, Koo SH, Atypical antipsychotic drugs perturb AMPK-dependent regulation of hepatic lipid metabolism, Am J Physiol Endocrinol Metab. 300(4) (2011) 624-32.

[55] Liu X, Wu Z, Lian J, Hu CH, Huang XF, Deng C. Time-dependent changes and potential mechanisms of glucose-lipid metabolic disorders associated with chronic clozapine or olanzapine treatment in rats, Sci Rep. 7(1) (2017) 2762.

[56] Lauressergues E, Staels B, Valeille K, Majd Z, Hum DW, Duriez P, Cussac D, Antipsychotic drug action on SREBPs-related lipogenesis and cholesterogenesis in primary rat hepatocytes, Naunyn Schmiedebergs Arch Pharmacol. 381(5) (2010) 
medRxiv preprint doi: https://doi.org/10.1101/2021.02.26.21252514; this version posted March 1, 2021. The copyright holder for this preprint (which was not certified by peer review) is the author/funder, who has granted medRxiv a license to display the preprint in perpetuity.

It is made available under a CC-BY-NC-ND 4.0 International license.

427-39.

[57] Jakel H, Nowak M, Moitrot E, Dehondt H, Hum DW, Pennacchio LA,

Fruchart-Najib J, Fruchart JC, The liver X receptor ligand T0901317 down-regulates

APOA5 gene expression through activation of SREBP-1c, J Biol Chem. 279(44)

(2004) 45462-9. 